\title{
Social Sciences at the World Bank and the Broadening of the Development Paradigm
}

\author{
An Essay in Honor of Michael Cernea
}

\author{
Ismail Serageldin
}

I joined the World Bank in 1972 as a 'Young Professional', recruited right after my graduate studies at Harvard. Over the years the Bank entrusted me with diverse jobs and responsibilities, mostly in the Middle East and Africa regions, regarded as the most difficult. This broad spectrum of assignments exposed me to many types of the Bank's activities, each one a school for understanding complexity and a place of experiential enrichment.

\section{The World Bank's First Vice-Presidency for Environmental and Social Matters}

However, as I'm now summoning my recollections, I have no hesitation to state that the most challenging and gratifying assignment I received during these years was when the then President of the World Bank, Mr. Lewis Preston, gave me the task to organize a new Vice Presidency - the Bank's first Vice Presidency for Environmentally Sustainable Development (ESD), My new task was to participate in implementing the designed expansion of the institutional architecture of the World Bank by building and inserting a new Vice Presidency-new both by content and by its functions-inside and outside the Bank, into the fabric of our daily work.

This happened in October 1992. We spent the next 2 months selecting and redeploying staff. The ESD Vice Presidency started its operations on Jan. 1st 1993. This assignment was at the moving frontiers of development goals and knowledge. Consistent with its Bretton Woods charter, the World Bank had been known as a giant economic and financial agency, supporting development projects.

\footnotetext{
I. Serageldin $(\bowtie)$

Library of Alexandria, Shatby, Alexandria, Egypt

e-mail: is@bibalex.org 
But the Bank's reorientation in the mid-1970s toward poverty reduction, revealed for all of us new and complex social realities and institutional requirements, which called for fundamental new policies and new knowledge.

During the 1980s, the Bank did make major steps toward a new development paradigm by adopting several original-indeed, pioneering at the international level—social and environmental policies and by introducing significant new practices, to which I'll refer in much detail further

Step by step, these pioneering new policies had incrementally broadened the Bank's conceptual and action paradigm. There were also initiatives taken by individual managers, of which I was one: a significant organizational innovation, for instance, was my decision to create in the Africa Region a distinct unit devoted to the "Social Dimensions of Adjustment"; another example was the international conference I initiated on "The Cultural Dimensions of Development". I was not the only manager to take such steps. But of course this was not enough to change the dominant paradigm in the Bank. Indeed, the Bank's internal organizational structure hadn't been simultaneously re-adjusted to its evolving goals and to its advances towards a new social development paradigm.

The pioneering work done by Michael Cernea in formulating a totally new Bank policy to openly confront the pathologies of forced expropriation and displacement, was a great service he did to the Bank itself, as well: he positioned the World Bank, in this respect, ahead of the entire international aid community. Remarkably, the Bank was equipped with that essential social-cum-environmental policy in 1980. That was fully 10 years before the Rio Earth Summit, and 15 years before the 1995 Social Development Summit in Copenhagen. That was a decisive reversal of the dysfunctional previous treatment of an entire category of social processes, but not yet a broad reorientation of the Bank's dominant development paradigm. That would come only by the reorganization launched by the Bank just after the time of the Bruntland Report and the Rio Earth Summit.

Indeed, shortly after Michael's success in writing and introducing the Bank's first social policy on resettlement, the Bank's social staff recommended and obtained the adoption in 1982 of the first Bank policy on Indigenous Populations adversely affected by development projects (Shelton Davis, Maritta Koch-Weser, and Michael Cernea). Further, after 2-3 more years of 'internal lobbying', Cernea also succeeded in 1984 in convincing the Bank's leadership to improve the operational policy and methods of project preparation and appraisal by introducing for the first time sociological analysis as mandatory for all the Bank's forthcoming projects, not only for certain categories of projects. The generalization of social analysis was achieved through a basic policy document (OMS 2.20 for Project Appraisal-1984) elaborated jointly by the Bank's lead sociologist working hand-in-hand with three other very senior Bank policy staff: an economist, a financial analyst, and an institutional specialist, to integrate all four key analyses used by the Bank for approving its investments.

The decisive events of the 1980s in broadening the Bank's development paradigm turned out to be those associated with the Sardar-Sarovar Dam project that was being financed by the Bank in India. Known as the Narmada project, it was severely 
criticized for its impact on the poor displaced by the project. Without discussing here India's primary responsibility, the shortcomings in the Bank's work were due not to a policy blunder, but to a deep internal organizational weakness. Indeed, policy-wise the Bank had a correct and robust policy framework. Michael Cernea was the first inside the Bank who sounded the alarm in 1982, during Narmada's project appraisal. He succeeded in postponing approval by the Bank's Loan Committee for one full year, to allow India the time to prepare a "rolling resettlement plan", since none had been prepared until then. But it was the Bank's lack of a central structure capable to ensure operations' consistency with policy that was the Bank's disabling inner organizational gap (see Robert Wade's chapter, this volume, for a documented description of how the Bank's regional operational Irrigation Division chief deliberately resisted and circumvented the Bank's policy, ultimately pushing the Bank into the Narmada fiasco). Wade's retroactive analysis depicts amazingly well how the Narmada case was not a case of absent policy, but a failure of the Bank's organizational structure to achieve consistency of some Bank staff's behavior and their adherence to policies that were already on the Bank's books. The Environment and Social Development (ESD) Vice-presidency was Lewis Preston's correct solution to filling the Bank's organizational gaps, to avoid actions inconsistent with Bank policies, and to promote best practices among the Bank staff.

My new task became to create a new component inside the Bank's institutional architecture, organically inserting a new Vice Presidency - the ESD, new both by substantive content, and new by its functions in the Bank's internal processes and in its external attributions. In addition, the ESD Vice-presidency included two other central departments: The Infrastructure Department and the Agriculture and Rural Development Department, together with the task of leading, on behalf of the Bank, the CGIAR research consortium.

\section{Working with the World Bank's Professional Sociologists and Anthropologists}

The ESD's creation in 1992 became possible also because the Bank already "possessed" an intellectually strong body of professional sociologists and anthropologists whose driving force and leader for over a decade was Michael Cernea (see Leif Christoffersen's essay, this volume, on Cernea's recruitment history). He indeed became sociology's most successful and creative 'Ambassador' for the Bank, and probably for international development aid agencies, beyond what anybody could have anticipated at his recruitment.

Indeed, the Bank was still slow and resistant to the new body of knowledge that Michael Cernea was showing and underlining. It took no less than 3-4 more years for the Bank to hire just only one rural sociologist as "young professional", Jacomina de Regt, and two other anthropologists, Maritta Koch-Weser and Gloria Davis, both outstanding, who were to also have brilliant professional careers at the Bank. Cernea 
was tenaciously fighting that initial snail-pace growth and kept advocating intensely for creating a 'critical mass' of professional social specialists and for placing them not only in agricultural divisions but in all of the Bank's sectors. He reached up to Bank senior managers and leading economists, like Warren Baum, the Bank's Vice President of the Central Policy Staff (CPS), Herman van der Tak, the CPS principal economist, Charles Weiss, the Bank's Senior Adviser for Science, and Montague Yudelman, Michael's Department Director, who after becoming familiar with his work became strongly supportive of Michael's initiatives.

Finally, a turning point in the Bank's hiring of social specialists occurred after Warren Baum convened in 1980 a key meeting of all OPS Program Directors, which was also an outcome of Michael's lobbying and networking (on this non-routine meeting, see Charles Weiss's essay, this volume, on how "a critical mass of social specialists" was created in the Bank.).

The 1980s decade indeed registered an accelerated and massive hiring of professional social specialists, and also a diversification of their work on the social variables of new sectors, beyond agriculture. They introduced changes into the Bank's project designs, in analytical appraisal methodology, and in implementation practices. When the ESD Vice-presidency was created in 1992 it inherited for its social work the precious "asset" of a tested community of social specialists that during the prior 12-14 years had built a substantial foundation of social policies (of which I'll soon talk in detail). Relying upon and enabling further this already existing in-house community of development sociologists and anthropologists, the new Vice Presidency was able to build, expand, and consolidate further.

\section{Building the Case for Using Social Science and for Converting Knowledge into Policies}

Further in this essay I will outline my perspective on the essential contributions of this community of social experts to the Bank's work, both before the existence of the ESD Vice-presidency, and thereafter, particularly contributions to the Bank's mission to reduce poverty and to counteracting development's risks and pathologies.

My own strong concern for social issues, as well as my collaboration and friendship with Michael Cernea, extend over a long professional timeline. We met at the World Bank decades ago and engaged in some common activities many years before ESD existed. It appeared that we both thought that the economic model being used by our institution was too narrow to deal with much of the broad set of essential variables of development, made even more complex by the very goal of reducing the dismal poverty that was devastating the developing world. Broadening the Bank's guiding paradigm required that the Non-Economic Social Sciences (NESS) play a much bigger role than they had in the Bank's structure and treatment of development issues. In the new ESD Vice Presidency, I had the pleasure to work directly with Michael Cernea, to appreciate him as a scholar, a professional and a colleague, and 
above all, as a human being. We remained friends after his retirement and after I left the World Bank in 2000 to become Egypt's Founding Director of the Bibliotheca Alexandrina (BA), which seeks, in the third millennium, to recapture the spirit of the Ancient Library of Alexandria. For 8 years Michael Cernea has been a member of the Board of Trustees of the Bibliotheca Alexandrina, and one of its very active instigators of social science conferences at the BA too. At the time of this writing, Michael remains a very active member in the Committee of Advisors to the Library's Director. Our close friendship and collaboration continues to this day.

In our years at the Word Bank, we found ourselves fighting on the same side of many issues. When I became the de jure patron of the Non-Economic Social Sciences (NESS) in the institution, Michael was the leader of the growing Bank community of social specialists. From a population of one (himself) in 1974, when he was brought into the Bank, the number of professional social specialists grew to some 160 staff in the mid-1990s. This was, as he rightly pointed out, the largest group of non-economist social scientists working together on development under the same institutional roof anywhere in the world. Furthermore, their work allowed them to be constantly in the field, gaining experiences that few of their colleagues based in academic establishments could match.

\section{Michael's Challenging Theoretical Argument}

After his first years in the Bank, during which he had understood what the Bank does, and how it does it, Michael had the intellectual courage to formulate a challenge to what he had observed. That was not just a challenge on the nuts-andbolts of putting one or another project together, but rather a theoretical challenge, a paradigm-level challenge, that was bold and surprising for a newcomer to make. $\mathrm{He}$ challenged the institution's one-sidedness in using the knowledge available from only the economic sciences. More explicitly, he critiqued the Bank for not taking into its mainstream thinking and practices the existing storehouse of knowledge offered by such social sciences as anthropology, sociology, social psychology, which are studying how the people whom the Bank defines as its "target population" live, act, think, interact, organize themselves for mutual help, for collective actions, and aspire to bettering their lives. He contended that not only actionable social knowledge was being omitted, and in this way, key dimensions of reality were being overlooked in the Bank's policies and projects, to the detriment of the Bank's clients and self-defined goals.

This was not a lightweight challenge. Michael had been brought into the Bank's house with a practical, yet narrow mandate: to help the work carried out on the experimental new type of integrated "rural development" projects with which the Bank was aiming to reach the rural poor. His initial given assignment was work on project after project, piece meal. He did this job well, but also did more: as he understood gradually better the World Bank, he was not content with just challenging one or another project or component. Michael challenged the institution's overall 
philosophy as one-sided and incomplete, and its methodology as obsolete, by not embracing and renewing its approaches in light of existent social knowledge germane to the Bank's development daily work.

Cernea constructed his challenge thoughtfully and systematically. Over a period of a few years, he prepared a full book, coherently argued, in which he not only raised fundamental questions but also constructively articulated feasible alternatives to the Bank's ongoing routines and conventional wisdom. He involved in that book other well-reputed scholars too, and titled his book unusually, as a manifesto: Putting People First (Cernea 1985).

The basic tenet of the book was that "People are-and should be-the starting point, the center, and the end goal of each development effort." And the book's subtitle explained conceptually what he meant, what the book was all about: 'The Sociological Variables of Development Projects.' Making good on the book's title and subtitle, he articulated clearly his theoretical platform in the first chapter of that seminal book, unambiguously titled: 'Using Social Science Knowledge for Development Projects and Policies.'

In the Bank's intellectual climate at that time, his whole idea-set was daring. $\mathrm{He}$ questioned the dominant position of economics in the Bank's thinking to the detriment of other forms of knowledge and expertise. He pleaded for the purposive use of non-economic social science knowledge for conceiving, inducing, planning, and managing development; and he didn't shy away from bringing up again and again ethics, explicitly invoking the Biblical commandment: "do not do unto others, what you don't want to be done to you". He also felt comfortable in discussing theory, and he launched his key challenge to the Bank starkly. Literally, the opening first sentences of his book's first chapter declared, without mincing words:

Several scientific disciplines, particularly economics, preside over the processes of planned development. But. . .sociology and social anthropology have not been called on by the Bank to serve extensively. Yet planning is a knowledge-based exercise. But the storehouse of knowledge and knowledge-generating methods amassed within the social sciences has been largely overlooked by the World Bank for several decades.

Cernea's critique of the dismissal of social science knowledge (except economics) produced by other social sciences germane to development work, continued unsparingly. In his constructive critique, he reminded the World Bank and all his book's readership, (which soon became international) of an unpleasant fact, namely the reasons for failure of many development projects. The premise of his reformist advocacy was a fact of elephantine size. The fact that a good number of projects registered failure was, obviously, not a novelty. But he pointed to a category of causes that had not been considered until then, declaring clearly that:

Repeated failures have plagued many development programs that were-and largely because they were-sociologically ill-informed and ill-conceived.

Being also a realist, Michael also conceded upfront that recognizing such a knowledge deficit, and overcoming it, will be "uncomfortable for development agencies" and would entail difficult intellectual clashes. Yet he insisted that, 
nonetheless, "addressing the social and cultural variables of projects" was indispensable, and will remain indispensable, for development effectiveness.

Michael didn't want his call for "Putting People First" to be only his personal argument. He invited a number of distinguished anthropologists and sociologists, the vast majority of whom had never worked before with the Bank, to produce a collectively articulated, mutually complementary, and factually documented argument. Moreover, he first invited each scholar-coauthor to the Bank to test their chapter with the Bank's practitioners by presenting their papers and reasoning in lectures, seminars and open discussions with the Bank's technical and economic staff. That strengthened each paper, which only became a chapter in the integrated book after going through an open debate inside the Bank. Furthermore, Cernea asked this roster of eminent scholars in social sciences to articulate what Putting People First means for project patterns in each one of some ten major economic development sectors or sub-sectors.

The book immediately made waves internationally. Such advocacy was unexpected from the World Bank and the book became an instant success for the Bank itself, not just for Michael. Book reviews were published in both developing and developed countries. The volume went into multiple print-runs. The then Director of the Bank's Publication Department invited Michael to become a member in the Department's manuscript review committee, to promote other comparable publications. Answering demand, a 2nd, enlarged edition of PPF, was printed. The book began to be translated and reached international audiences in five languages, including in China, Japan, Latin America, Indonesia, and France. Its seminal influence on the international development community and in Universities surpassed all expectations, and continues today.

\section{Converting Social Science Knowledge into Social Policies: A Historic Progress}

When I'm arguing that today social sciences are more important than ever in inducing development, I'm fighting the same fight like at the Bank, years, but this time from the tribune of the new Library of Alexandria. The message is the same that Michael and I fought for at that time: namely, to give space to the Non-Economic Social Sciences (NESS) in decision making, in policies, and in projects.

A historic series of institutional stepping-stones started in 1979/1980 with the writing and adoption of the Bank's first social policy, the policy on involuntary resettlement. This first step continued with the adoption of a sequence of Bank landmark social and environmental policies throughout the 1980s. The cumulative effect of these policies enlarged the Bank's theoretical and operational paradigm, contributing measurably to the Bank's gradual shift from its traditional economic growth doctrine toward the broader paradigm of social development. Implementing these policies demanded more in-house staff social specialists to expand the Bank's 
work and to assist the Bank's borrowers in absorbing these policies in their work preparing new projects for Bank financing.

Those new and pioneering social policies were:

- 1980: The policy on Social Issues Associated with Involuntary Resettlement in Bank Financed Projects (WB OMS 2.30 February)

- 1982: The Policy on Indigenous (Tribal) People in World Bank Financed Projects (WB OMS 2.34)

- 1984: The Policy on Sociological Analysis at Project Appraisal (WB OMS 2.20) introduced for the first time social analysis as mandatory for the preparation and appraisal of all Bank financed projects'. This policy was the first that brought up at the Bank's policy level the issues of women in Bank projects

- 1984: The first World Bank Environmental Policy (1984)

- 1986: WB Operational Policy Note. (10.08) Involuntary Resettlement that substantively strengthened and broadened the Bank's first Involuntary Resettlement Policy

- 1986: The protection and preservation of Physical Cultural Heritage affected by World Bank financed projects civil works: chance finds (WB OMS 1986)

- 1988: Policy Guidelines for Implementing the World Bank Involuntary Resettlement Policy. This World Bank Technical Paper consolidated and detailed the 1980 and 1986 resettlement policy documents; it was intended to make public for the first time the Bank's resettlement policy for increasing its impacts (Cernea, M: Policy Guidelines on Involuntary Resettlement. World Bank Technical Paper $\mathrm{nr} 80$ )

- 1989: World Bank OMS: “Involving Non-Governmental Organizations in Bank Supported Activities"

- 1990 World Bank. "Primary Education: A World Bank Policy Paper"

- 1991 World Bank. "The Forest Sector. A World Bank Policy Paper"

- 2001: Cultural Heritage and Development. A Framework for Action in the Middle East/N. Africa, The World Bank, Washington DC

Some of these policies marked a huge progress not only for the World Bank, but were also novel ideas replicated gradually by OECD countries' bilateral aid agencies and by the regional multilateral development banks.

The institutional and functional necessity of a specialized central Vice Presidency for dealing with the work requirements of this new body of social and environmental policies became increasingly obvious. This was needed for continuing this conceptual and guidance work on new issues such sustainability, social capital, and others. ESD Vice-presidency's influence inside the Bank resulted also from its capacity to bring up social, cultural, and environmental concerns at the top decision making levels of the Bank, due to which, the social and environmental policies were taken much more seriously into account by the Vice Presidents leading the Bank's large operational regional vice-presidencies of the Bank, within which the bulk of the Bank's staff at large is working. 
By about mid-1990s, the World Bank's growing community of social scientists led by Michael Cernea, many recruited by him directly, had reached its peak intellectual power, institutional influence and numerical size inside the World Bank. Thus, the World Bank benefited from stellar rosters of staff anthropologists and sociologists, such as Gloria Davis, Maritta Koch-Weser, Shelton Davis, Scott Guggenheim, Deepa Narayan, David Butcher, William Partridge, Ashraf Ghani, Cyprian Fisiy, Cynthia Cook, Marlaine Lockheed, Stephen Heineman, Michael Bamberger, Augusta Molnar, Nat Colletta, Daniel Gross, Lynn Bennet, Dan Aronson, Chona Cruz, Stan Peabody, Paul Francis, Elena Correa, Jorge Uquillas, and others. As the leading development anthropologist scholar Thayer Scudder noted, Michael Cernea "was the force behind the recruitment of additional social scientists that in time became the largest group dealing with development-induced resettlement" (Scudder 2005).

In addition, numerous academics from universities and research institutes were invited to offer lectures to the Bank's staff-among them Fredrik Barth, Robert Chambers, David Maybury-Lewis, Neil Smelser, Shi Guoqing, Gunnar Sorbo, Thayer Scudder, Walter Coward, Hari-Mohan Mathur, Conrad Kottak, Theodor Downing, Hussein Fahim, Alf Jerve, Balaji Pandey, Warren van Wicklin III, Abdul Salam, Michael Horowitz, Caroline Moser, and uncountable others.

In turn, the activities and influence of the World Bank's community of social scientists working as development practitioners had also a radiating intellectual effect: it became a centrally located force, with growing world-wide intellectual influence that was unmatched in other multilateral development banks; a force that in turn provided support and interacted with large cohorts of sociologists and anthropologists in developing countries, who previously were latent "onlookers" (see Mohan Mathur essay, this volume) or involved only in teaching.

This tribute to the Bank's community of social specialists and social science scholars would be incomplete without my respectful acknowledgement of the value, richness, and originality of the vast body of research publications they created over years of working, thinking, and writing. This body is solidified knowledge. Without it, development anthropology and development sociology would not be the disciplines that they are today. Michael Cernea has been and remains an indefatigable writer, published then and today, known and studied in numerous countries. Together with him, scholars and writers such as Scott Guggenheim, William Partridge, Maritta Koch-Weser, Deepa Narayan, Lynn Bennet, Nat Colletta, Maria Clara Mejia, Anis Dani, and others produced a cornucopia of excellent evaluation studies, position papers, policy guidelines, innovative lending instruments, handbooks and sourcebooks, etc. The intellectual influence of this strong group of social scientists, remains felt today, through their writings, within both the international development and academic communities (see the annotated bibliography by Cernea and Adams 1994; Davis 2002). 


\section{The World's Largest Empirical Research on Development-Forced Population Displacement and Resettlement}

In the wake of Narmada's globally resounding resettlement failure, Michael Cernea conceived a new and ambitious brain-child. Beyond the clash around the Narmada project that had "sucked-in" all management's attention, Michael remained concerned about the fundamental matter: the health of the Bank's entire ongoing project portfolio involving resettlement. Narmada's stormy events were not yet over when Michael went to the Bank's Senior Vice President, Ernst Stern, and proposed that the Bank undertake a review of its entire project portfolio to identify all ongoing projects plus those in the preparation pipeline that may have displacement effects and analyze whether there are other "hidden Narmadas" which might explode sooner or later. The kind of review he suggested was much more than a simple deskstocktaking. He recommended an action-oriented empirical field-research. Another novelty he proposed was for the review teams to not only identify projects-withproblems, but also to have the authority to initiate on-the-spot remedial actions for making such projects consistent with the Bank's resettlement policy. I gave that proposal my full support.

Bank management approved Michael's proposals. The Bank's President, Lewis Preston, appointed in 1993 a Task Force headed by Cernea with broad powers to analyze all 1986-1993 projects causing forced displacement. A Steering Committee, chaired by myself as the founding head of the new ESD Vice-Presidency, was to ensure the cooperation of all operational Bank Vice-Presidencies

Cernea worked closely with another eminent anthropologist, Scott Guggenheim. For the review's field activities, a strong segment of the larger community of social specialists was marshalled. The review covered almost 200 projects under implementation between 1986 and 1993, an analysis unprecedented for any other Bank issue. As Chairman of the Steering Committee, I worked closely with the Cernea-led Resettlement Task Force.

The Bank-wide review ultimately became a book-size study, with two print-runs (see Cernea et al. 1994/1996). This was not the kind of routine World Bank deskreview. That was an incisive analytical field-study, with unique features that elevated the study's caliber and results. First, it covered not just a selected small sample, but the largest ever collection of real projects (192 projects), enabling robust findings and substantiating credible generalizations. Second, it employed a competent research-and-action staff force, sent out to dozens of countries to empirically assess the real-on-the-ground-state of resettlement. Third, it had a capable, honest and uninhibited leadership in the central Task Force. Nominally, the central Task Force consisted of only four persons, named above; yet, at Michael Cernea's call, in practice virtually all Bank social specialists took part in one or another role.

As a result, the study produced new insights and strategic recommendations for the Bank and its member governments on their performance, failures, and on how to improve resettlement planning and livelihood outcomes. It also equipped the 
emerging social science domain of displacement/resettlement with a text-book methodology on how to analyze such processes, their risks and outcomes.

The Bank's Board of Executive Directors and the Bank's Management adopted all the Task Force recommendations - a genuine coronation of the Task Force's efforts. This reinforced the internal respect inside the Bank for resettlement operations. Following the study's recommendations, Bank management decided to increase further the number, role, and resources of the Bank's social staff. The study defined seven strategic priorities for the Bank's further work on resettlement. The Bank became more capable for providing hands-on assistance to our borrowing countries to minimize involuntary resettlement whenever possible, and carry it better when such resettlement was unavoidable.

Even the critics of the World Bank from the NGO community gave exceptional praise to the review's quality and candor. A book on accountability in development by Fox and Brown concluded that:

The World Bank's 1993-1994 resettlement review set a still unmatched precedent in terms of rigor, comprehensiveness, transparency, and self-criticism. Inside reformers strategically used public transparency as a tool for increasing institutional accountability, defined as compliance with reform commitments... and was produced with strong support from the vice president for Environmentally Sustainable Development.

For myself too, I must say that my participation in the 1993-1994 study was a powerful eye-opener. It revealed weaknesses in the quality of some of the Bank's work that I did not suspect; nor were other senior Bank managers aware of them. I felt that due to the principled manner in which the analysis was conducted, particularly its field action-research method, the resettlement review set a model of trenchant and candid analysis of quality in Bank-financed projects, worthy of replication beyond resettlement. Therefore, while the task force members returned to their other duties, I brought up the issue of a "crisis of quality" in the inner discussions of the Bank's management. I felt that similar grave inconsistencies between Bank policies and practice may lurk beneath the surface in other sectors of Bank work. The example set by the resettlement study became my recurrent reference, a "proof" for my arguments. I wrote two memoranda on quality issues to the Bank's management team (Serageldin 1995a, b), in which I argued that the resettlement review gave us lessons and a pattern of how management should further analyze consistency in policy implementation, and that the work-style of the review should be leveraged towards further culture change inside the Bank. Verbatim, I wrote:

I am encouraged to push in the direction of the Resettlement Review by its results. There, we had a $100 \%$ review of the portfolio and the pipeline. Sociologists, anthropologists, economists, and other specialists reviewed every report by the regional staff and participated in repairing problems as they found them. Regional management was reporting monthly to the President's office....

All these efforts not only improved standards, but also changed the culture in many of the Bank's Departments. At the retreat of the Bank's sociologists and anthropologists, which followed the Bank-wide Resettlement Review, they spoke 
of its effects on how the attitude in their department had changed not just about resettlement, but about other social issues. This prompted me to call for similar portfolio reviews in other sectors:

Nothing less than this kind of systematic and intensive scrutiny, supported at the highest levels of management will be able to bring about the culture change needed in the Bank. (idem, 1995b).

I must add that it is to the credit of the Bank that it allowed such candid discussion of all issues within and outside its walls. The directness of the critique and the quality of the debate around its findings would be difficult to imagine in many other institutions, especially in many of the governments whose projects the Bank finances and supports.

\section{The Emergence of the Impoverishment Risks and Reconstruction Model}

Surely, the deepest foray made by this study was in conceiving the insightful model or pattern of multiple risks revealing and documenting the financial, economic and social risks of becoming impoverished, jobless, homeless, and marginalized are risks that confront the poor when they are exposed to expropriation of assets and physical displacement. To do so, it validated and applied the model conceived by Cernea (see Cernea 1997), defined by him as "The Impoverishment Risks and Reconstruction model", mischievously summarized in the acronym "IRR", which for most economists means "Internal Rate of Return" for the economic analysis of project investments. It is thus appropriate to give some thought to how the IRR model has enriched the theory and methodology of resettlement research The Cernea IRR model became the single most influential social science analytical tool in to reshaping the thinking on forced displacement and resettlement processes.

The IRR model had its theoretical and empirical origins outlined gradually before the review but this was the first large-scale test of the IRR model on the universe of the Bank's all projects ongoing then. Ultimately, this vast body of empirical evidence convincingly confirmed its explanatory power. The publication of that study was what placed the IRR model solidly on the map of international development social science as a tested tool for diagnosis, remedial planning, research and performance evaluation.

Which are the most common impoverishment risks from displacement? How can they be countered? Cernea's research deconstructed the empirical evidence and concluded that there are recurrent processes that give rise to impoverishment along eight main variable dimensions of poverty: landlessness; joblessness; homelessness; marginalization; increased morbidity; food insecurity; lack of access to common property; and social disarticulation (Cernea 1997; Cernea and McDowell 2000). In addition, affected people may face other risks as well, emerging from specific project/context circumstances, but these eight risks are most important and virtually 
ubiquitous, even though their intensity does vary in every case by sector or by other parameters like family size, gender, age, time, etc., as Cernea has explicitly stressed (1997). For instance, specialized research on displaced women has consistently confirmed the IRR model and its explicit assertion that women suffer more severe impacts than men and may be exposed to additional specific risks. When the risks of impoverishment aren't targeted through counter-risk measures included in the projects' context, it is certain that they will morph into real and economically detrimental effects on people's welfare.

\section{A Self-Destroying Prophecy and Unprincipled Censorship}

The operational effectiveness of Cernea's IRR model resides not only in its risk analysis, but also, and even more, it resides in the model's 2nd part. Indeed, the IRR's second "half" outlines the response strategy for each impoverishment risk, one after the other. These elements can effectively counter-act the risks outlined in the model's first part by directing reconstructive actions in the desired and needed areas. This part is not less important than the risks themselves: the two parts are germane to each other. The second part is modeling the processes of economic and social rehabilitation and improvement of the livelihood of the families affected by displacement. The IRR model's operational usefulness to practitioners anywhere would be limited if the model itself only revealed risks but said nothing on how these risks can be dealt with.

As Cernea has explained (see also his chapter on the IRR model, this volume) he embraced the argument of a giant of modern sociology - Robert King Merton. Merton famously deconstructed the paradox of "self-destroying prophecies" and argued that, under certain circumstances, some predictions (or prophesies) can change social behavior and can trigger actions that prevent the predictions from fulfilling themselves : hence, "self-defeating prophesies".

By using correct and strong concepts to inform project planners on how deeply toxic the risks inherent in forced displacement are, Michael aimed to determine those responsible for each project causing displacement to plan all needed to reverse and prevent impoverishment from happening.

Yet, even inside the IRR's intellectual home, its message did not enjoy an easy ride. I will turn to some of the in-house battles that the IRR model had first to fight and win inside the Bank in order to become an instrument publicly known and used in many other places beyond the Bank itself. I was a party to some of those battles. Now, decades later, I'm pleased to share some of my observations as an insider.

The model's description of displacement's intrinsic impoverishment risks scared some of our colleagues One concern about the review, expressed during its unfolding was related to fact that it asked for a transparent recognition and analysis of the risks imposed upon the displaced populations... Several attempted to silence it by questioning its "political usefulness" and "appropriateness." Mostly, they were 
scared by the model's candid terminology about risks, and they didn't want it included in the review's report to the Board and to the public.

Having to oversee the review process on behalf of the Bank's senior management, I had to respond. From the supervisor of the Team's work, I became their advocate in the management circles of the World Bank.

Surely, project documents mentioned some risks, but these were routinely macrorisks, foreign exchange risks, and supply risks. Some of our colleagues objected against what they saw as the Bank's communicating to the wide world that its own projects cause risks. Today, two full decades later, this may sound strange and would be labeled "concealment of risks." Effectively, they reacted negatively to the review's detailed articulation of the impoverishment risks from displacement as problematic in a major Bank review. The opponents claimed that the report will "alienate" many officials of the borrowing governments because they don't like to admit such risk to their own publics. Some termed the IRR concepts as "inflammatory" likely to confirm NGO's public criticism of the Bank based on the Bank's "own admission."

Cernea refused to accept such comments as valid and declined to compromise the review's analysis of impoverishment. He argued that the terminology was empirically documented and theoretically correct. Diluting the truth-telling through some rosier wording would undermine the goal of creating genuine awareness about the catastrophic effects of expropriation, uprooting, joblessness and other losses. The team argued that "keeping silent about risks" would not make the risks go away from Bank-financed projects. On the contrary, the unaddressed risks would only fester and would surface with added virulence because they were not recognized and tackled in a timely manner. I supported the team's position.

For a while, the battle for candor seemed largely won by the review's Task Force. But when the draft's chapters started to come in for management's review, its explicit and strong concepts — such as, "landlessness", "joblessness", "homelessness", "increased mortality and morbidity," and so on- caused a wave of objections.

Again, I supported Cernea and his team. In the end, the powerful logic of the model itself, the steadfastness of its proponent, and perhaps not least the backing by the review's Steering Committee, prevailed over defensiveness. The Task Force's review was published as written, uncensored. The evidence-based model of a typical pattern of impoverishment risks, including the counter-risk remedies it recommended, remained at its center.

Subsequently, after the Bank-wide study was completed, and its authors were congratulated by the Bank's Board, I returned to the "semantics" of the IRR model during a private conversation with its key author. Cernea gave me two reasons for his refusal to soft-pedal the impoverishment risks. I must say I not only endorsed but also fully liked his reasons and his steadfastness. He had both general and personal motivations.

First, Michael reminded me of his work as a sociologist during the dictatorial communist regime in his country of origin, Romania. That regime, he said, imposed not only official censorship over published writings, but also put a pernicious 
systemic pressure to induce self-censorship. That was very demeaning, and he had costs to pay for refusing to yield to censorship. Now he was determined to resist at the World Bank any notion of forbidding the discussion of new concepts. I couldn't support more his feelings, having had to fight censorship myself

Second, Michael emphasized that he had a purposive communication strategy, because he had to overcome a paradox intrinsic in the Bank's work. His choice of strong concepts in predicting displacement's fundamental impoverishment risks was deliberate, not accidental. He had for long concluded that the causation of new poverty through displacement did not receive the unvarnished exposure it needed. He therefore needed terms that would compel everybody's attention. Therefore, for the risks he identified empirically, he selected true and strong concepts to trigger the awareness of Bank staff and managers that making people worse-off was an unacceptable violation of development ethics and of World Bank normative policy, which couldn't be tolerated simply because the Bank-financed projects were "aimed to serve the greater good". Bank-financed projects are undermined by a perverse paradox: even while they do reduce poverty for some people, they can be causing harm and new poverty to some other people. So he said:

\footnotetext{
But this is not an unsolvable paradox. I've seen and lived through forced displacement myself, with my family. The knowledge of displacement's ugly effects is in-printed in my own DNA, indelibly. by personal experience. I'm therefore determined to trigger intolerance to poverty creation, through all available Bank means: more financing; technical planning; moral reasoning; and - why not—correct strong precautionary semantics too. Moreover, through my IRR model I'm not just disclosing risks passively/contemplatively: but I'm also defining for each intrinsic risk the pragmatic strategy to prevent potential risk from becoming real impacts. Loudly branding impoverishment risks is like sounding the alarm: making them impossible to ignore is my prophesy-destroying strategy.
}

That was a memorable conversation which made me understand Michael better. This is why he refused to eliminate the concept of "impoverishment" from the name of his model and declined to employ softer concepts for defining the risks themselves and insisted on keeping them as he had labeled them. By now all people speak of the risks of "landlessness, joblessness, homelessness," and so on.

By his determination to call risks by their proper names without "beating about the bush", Cernea sought to expose the tragic reality of what is still frequently occurring in development practice. This was not intended to inflame criticisms of the Bank: it was aimed to mobilize the determination of his colleagues, and not least the agency of the risks' bearers, to confront and fight the ills that he unambiguously identified. That determination was aggravating to some in the short term, but it left its mark on many in the long term. I gave my full backing to the necessity of addressing these risks, and today, over two decades later, it is clear that the global resettlement literature has mainstreamed the risks of impoverishment, showing that forcefully exposing the unpleasant realities was the right thing to do.

During the quarter century that passed since the Resettlement Review, the IRR model went on to become a very impactful tool, the most employed internationally analytical instrument in social science research on resettlement. Its conceptual apparatus about risks has become current vocabulary, current currency. Far beyond 
the World Bank, it is used and validated in countless studies, books, handbooks, training manuals, reports, journal studies, international conferences, etc. (see earlier, footnote 1).

\section{Knowledge Alone Is Not Enough. Political Will Is Indispensable to Stand Up Against Impoverishment}

The science of handling population resettlement issues as a domain of social sciences has registered a massive enrichment in its conceptual apparatus and recommended methods. Looking back to when the first institutional policy on population resettlement was formulated, this domain was rudimentary, only incipient, undeveloped. Over a relatively short period of time, the progress has been exceptional. The impoverishment risks and reconstruction (IRR) framework has made its contribution to this growth, and new concepts and research trends are emerging.

Displacement failures today are increasingly being seen not only as unacceptable impoverishment pathologies but also as major aggressions against basic human rights. The conceptual vocabulary of human rights, which development agencies have long tried to avoid, is making inroads in resettlement theory being absorbed by scientists and activists into the argument for sustainable post-displacement reconstruction. Philosophers and ethics researchers are joining the ranks of displacement scholars; from their perspectives, they're questioning the morality of predicating the pursuit of profits for some (or even for the "public interest") on ruining the existence and livelihood of others, robbing Peter to enrich Paul (see, among others, Penz et al. 2011). Legal theory and legislation are advancing towards defining certain forms of forced population displacement as a "crime" punishable by laws.

Overall, no one can any longer claim today-be they governments of private sector corporations - that they didn't know about, nor that they could not anticipate the negative impacts and pathological effects from the forced displacement caused by a development project. Indeed, we now have a body of knowledge that is much more advanced than the level at which development projects and resettlement processes are implemented. The failures of timely post-displacement recovery are more frequent than successes, largely because the governments (or other entities) owning the projects are not willing to do the responsible planning and allocate the necessary financing. Though a complex process, involuntary resettlement is neither technically nor socially intractable; it can be conducted successfully. Thus, the ball is in the court of the governments, of the public agencies, and of private sector corporations which sponsor and own projects that cause expropriations and displacement.

My own involvement in international development taught me that the decisive factor is the political will of public aid agencies and the political will of developing countries' governments. The extent to which the government of each country has the 
political will to deal with involuntary resettlement sustainably is precisely the extent to which it will work or fail. Emphasizing this fact, a World Bank evaluation study went as far as to recommend that governments which do not have the political will and commitment to handle involuntary resettlement soundly should not be supported to embark on such project at all (Picciotto et al. 2001). This was a fair warning. ${ }^{1}$ Commensurate financing, the quality of the reconstruction plan, and the extent to which impoverishment risks are deliberately counteracted, makes or breaks the success of resettlement.

There is no one single variable, no silver bullet that can resolve this conundrum. There is one central factor, though, that can connect all that is needed, and that is the presence of political will. This is necessary at both the level of the state, and of the private corporation, since nowadays displacement is caused by private and public projects alike. It is only when political will is exercised that the needed resources can be mobilized, including financial resources, and when there are better chances that the impoverishment risks inherent in forced displacement can be arrested before morphing into a range of painful social pathologies.

Yet unfortunately, political will isn't a constant and the philosophical outlook does not remain continuous: it sometimes changes from one government to the following one, changes with the succession of political leaders, or with managers of international public agencies. Even in an agency as stable as the World Bank changes can occur unexpectedly, largely reflecting the leadership style of the President of the Bank and his or her philosophy. Following the unexpected death of President Preston in May 1995, the Bank was lucky to get a dynamic leader in the person of James Wolfensohn. Wolfensohn was a strong advocate of keeping a focus on the fight on poverty, and was sensitive and very insightful on the non-economic dimensions of development, including social and cultural variables. I left the Bank to return to Egypt during his presidency.

Regretfully, after President Wolfensohn, President Paul Wolfowitz was appointed as Bank president in June 2005. He abolished the ESD vice-presidency, to the surprise of many Bank staff. That was a major setback to the ongoing progressive evolution of the Bank and of its social and environmental safeguard policies, described earlier in this paper, that already had gained broad international constituencies, including not only all other MDB's (the Multilateral Development Banks) but also of some 70-80 giant private sector banks that had adopted many of the same policies under the banner name of the "Equator Principles Banks". The Bank's central ESD staff was dispersed, diminishing the Bank's capacity to promote and monitor consistency of the projects' content and implementation with the Bank's statutory policies. The weakening of the Bank's central set up also facilitated subsequent further changes as well, expressed in the recasting and replacement of the cluster of ten explicit safeguard Bank Policies (BPs) and Bank Operational

\footnotetext{
${ }^{1}$ The proposal to give this warning to borrowers was made in 1994 by an Executive Director of the World Bank during the Board's discussion of the Portfolio Resettlement Review (World Bank 1994).
} 
Procedures (OPs) with an environmental and social framework (ESF) and a set of standards (ESS) which were declared by the Bank as "binding" for all the Bank's borrowing countries. In effect, the bank was telling the countries/borrowers what was expected of them to do, but absolving itself of any responsibility if they did not follow the recommended policies and procedures. This was an enormous setback, as the Bank's specialized and highly qualified technical social and environmental staff, were dispersed into the regional staff teams, with little authority to review the risks associated with the proposed operations. The dispersal of the central staff weakened the critical mass of the Banks non-economic social staff, whereas such a critical mass had in the past been the source of much innovation and could in the future have continued to innovate in the application of new knowledge onto the thinking about development and linked that to actual performance in the field. It is to be welcomed that the past achievements were not totally lost, and that the broadening of the Bank's paradigm remained a reality, even if the implementation of that broadened paradigm was rather weakened in some areas.

I mentioned the episode described above in order to stress that progress hasn't occurred as an uninterrupted ascent. Every advance needed to be defended and strengthened continuously. And I am happy that the broadening of the Bank's social development paradigm had become already irreversible and under the drive and commitment of some individuals of excellence it continues to advance further.

\section{Closing Thoughts on the Impact of the ESD Central Vice-Presidency on the Work of the World Bank}

In addition to other important activities described earlier, the Bank-wide Resettlement Review was the first large Bank-wide activity under the aegis of the new ESD Vice-presidency it was to be followed by many other initiatives. The IRR model that it launched internationally, was one of Michael Cernea's most important contributions to the Bank and to development thinking generally. Inside the Bank, it was a triumph of how a central vice-presidency should work with regional operational staff and with borrowing countries on one of the thorniest processes in development.

The World Bank is remarkably well endowed in talent. The staff of the Bank are, by far, its most important resource. They bring exceptional professional skills to bear on the problems of the poor in this world. The Bank is also a place of innovation, where intellectual sparks fly and where the debate is forceful, professionally demanding, and characterized by a hard edge of intellectual rigor, and informed by pragmatism too. Many of the intellectual movers and shakers inside the Bank are seldom known outside the institution. They derive their satisfaction from having pushed the institution's process of conceptualizing and practicing development along the lines they think are right. 
The existence of a solid group of social scientists in the central ESD vicepresidency enabled the Bank to place additional tasks on the shoulders of this precious human resource of the Bank. They had review functions to carry out, to ensure compliance with policies by Bank central and country based staff (sometime weakened by centrifugal tendencies). They also performed intellectual services beyond the Bank, such as participating in and organizing international social science conferences, and regularly inviting outside eminent scholars for lecture for the Bank staff. For example, the ESD vice presidency co-organized in 1995 and 1996 two consecutive international conferences with Oxford University. These two conferences resulted in two influential books.

During the last 5 years I had spent in the Bank, from 1996 to 2000, before returning to Egypt to revive in our modern times Antiquity's Library of Alexandria, the ESD Vice-presidency was a key actor in promoting and broadening the Bank's social development mission and paradigm. Those 5 years coincided with the first period of Jim Wolfensohn's presidency of the Bank. It was not a coincidence that Michael Cernea sought and succeeded in the first weeks of Jim's work's in the Bank to capture his attention and personal support to the work, role, and needs of the Bank's community of social specialists (see Davis et al. 1998). Michael's written proposals to Jim Wolfensohn lead to a full scale Bank-wide Social Development Report (World Bank, 1997) that was submitted to the Bank's Board, which then decided to institute a distinct "Social Compact" program and a very substantial financial allocation for further expanding the resources, staff, and activities of the Bank's social specialists. I engaged myself, with Cernea, Kreszentia Duer, Katherine Marshal, in organizing a series of international Conferences on the Bank's support and investment projects for preserving better the developing countries' material Cultural Heritage. Michael Cernea was then invited back from retirement to research and write the World Bank's first formal policy framework for the Preservation of the Cultural Heritage of the Middle East and North African Countries (Cernea 2001)

By the time Michael Cernea and I left the Bank, the institution was equipped with a groundbreaking set of policies, called the "Environmental and Social Safeguard Policies". These aimed to ensure that Bank staff worked with our member governments to try to ensure that each operation was as well-designed as it could be, and that the cynical concept of "tolerable collateral damage" would never be resurrected from history's garbage bin.

Development remains a complicated and often messy process on the ground, with the rich and powerful displacing the poor and the weak. The role of the Bank remains the same but does expand in depth and breath: to eliminate poverty, avoid producing new poverty risks, and eliminate any negative economic, environmental or social side-effects of the projects that the Bank finances.

Even inside the Bank, and despite its fundamental commitment to social development, we've also noticed periodic bouts of resistance by misguided managers or poorly trained individual staff to the institution's social and environmental safeguard policies. The Bank's in-built responsibility is to overcome such departures from its mission. This is why I must also say that I was surprised and unhappy when Mr. Paul Wolfowitz, who came to the Bank after the enlightened tenure of President Jim 
Wolfensohn, erroneously decided to abolish the central ESSD Vice-presidency and thus undercut he Bank's actual policy and operational work on these core issues. This reduced the value of the Bank's investments to all countries, developed or developing. The Bank's organizational structure was weakened, not strengthened, by eliminating its central part, indispensable functionally to the social and environmental sustainability of its investments, with adverse effects in practice. I know that most of the work we had done remains integrated into the fabric and thinking of the Bank. The need to further improve the performance of its fundamental mission remains today as strong as ever.

I mentioned the episode described above in order to stress that progress doesn't occur as an uninterrupted ascent. Every advance needs to be defended and strengthened continuously. And I am happy that the broadening of the Bank's social development paradigm had been already irreversible and under the drive and commitment of some individuals of excellence it continues to advance further

My deep confidence, in this salute to Michael Cernea and his contributions, is that by now much of this knowledge has spread internationally and many countries and many development agencies are by now endowed with capable social scientists of their own, working on development. That will be the real legacy of the work of all the militant social specialists celebrated in this chapter.

My further hope is that new generations of social staff - with the same vigor as generations past - and applied social scientists in many countries will benefit from the new landscape being created by the revolution in science and technologies, and succeed in keeping the paradigm of social development constantly evolving to ensure that it benefits all the people. The enlightened practices of the few ought to become the current practices of the many.

\section{References}

Cernea, M. (1985). Putting people first: Sociological variables in development (1st ed., 2nd ed. 1991). New York: Oxford University Press.

Cernea, M. (1997) The impoverishment risks and reconstruction model for resettling displaced populations. World Development, 25(10).

Cernea, M. (2001). Cultural heritage and development. A framework for action. Washington, DC: World Bank.

Cernea, M. (2015). Landmarks in development: the introduction of social analysis in project appraisals. In S. Price \& K. Robinson (Eds.), Social assessment policy and praxis and its emergence (pp. 35-59). New York: Berghahn.

Cernea, M. Poverty risks from population displacement in water resources development. Harvard University: HIID. Development Discussion Paper No. 355.

Cernea, M., \& Adams, A. (Eds.) (1994). Sociology, anthropology, development: An annotated bibliography of World Bank publications 1975-1993. With a foreword by Ismail Serageldin. Washington, DC: World Bank.

Cernea, M. M., \& McDowell, C. (Eds.). (2000). Risks and reconstruction: Experiences of resettlers and refugees. Washington, DC: World Bank.

Cernea, M., Guggenheim, S., Aronson, D., \& van Wicklin, W. (1994/1996). Development and resettlement. The bank-wide review 1987-1994. Washington, DC: World Bank. 
Davis, G. (2002). A history of the social development network in the World Bank, 1973-2002. WB Working Paper. Washington, DC.

Davis, G., Steer, A., \& van Wicklin, W. (1998). Michael makes his mark. The life and times of a change agent in the World Bank. Washington, DC: Social Development, World Bank.

Penz, P., Drydyk, J., \& Bose, P. (2011). Displacement by development: Ethics, rights and responsibilities. Cambridge University Press.

Picciotto, R., van Wicklin, W., \& Rice, T. (Eds.) (2001). Involuntary resettlement. Comparative prospective (Vol. I and II). Washington, DC: W.B. Evaluation Series.

Scudder, T. (2005). The future of large dams (p. 22). London: Earthscan.

Serageldin, I. (1995a). The crisis of quality: Reflections and recommendations. Note to Bank Senior Managers. April 25. Processed

Serageldin, I. (1995b). Detailed recommendations for improving quality management in the bank: Suggestions. Processed. July 14.

Ismail Serageldin, Emeritus Director, Library of Alexandria in Egypt. He serves as Chair or Member of a number of advisory committees for academic, research, scientific and international institutions and civil society efforts. He is a member of the Institut d'Egypte (Egyptian Academy of Science), US National Academy of Sciences (Public Welfare Medalist), the American Philosophical Society, The World Academy of Sciences (TWAS), the World Academy of Arts and Sciences (WAAS), the Indian National Academy of Agricultural Sciences and the European Academy of Sciences and Arts. Previously he has been Vice President of the World Bank (1992-2000), former Chairman, Consultative Group on International Agricultural Research (CGIAR, 1994-2000), Founder and former Chairman, the Global Water Partnership (GWP, 1996-2000) and the Consultative Group to Assist the Poorest (CGAP) (1995-2000). He was Professor at the Collège de France, Paris, and Distinguished Professor at Wageningen University in the Netherlands. He has received the Order of the Rising Sun from Japan and the Legion d'Honneur from France and is a Commandeur of Arts and Letters of the French Republic. Serageldin has published over 100 books and monographs and over 400 papers on a variety of topics including biotechnology, rural development, sustainability, and the value of science to society. He holds a Bachelor of Science degree in engineering from Cairo University and a Master's degree and a $\mathrm{PhD}$ from Harvard University and has received over 35 honorary doctorates.

Open Access This chapter is licensed under the terms of the Creative Commons Attribution 4.0 International License (http://creativecommons.org/licenses/by/4.0/), which permits use, sharing, adaptation, distribution and reproduction in any medium or format, as long as you give appropriate credit to the original author(s) and the source, provide a link to the Creative Commons license and indicate if changes were made.

The images or other third party material in this chapter are included in the chapter's Creative Commons license, unless indicated otherwise in a credit line to the material. If material is not included in the chapter's Creative Commons license and your intended use is not permitted by statutory regulation or exceeds the permitted use, you will need to obtain permission directly from the copyright holder.

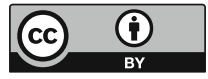

